\title{
Intervensi psikososial bagi mahasiswa terminasi PPSK Fakultas Kedokteran UNISSULA Semarang
}

\author{
${ }^{1}$ Ahmadi Nur Huda*, ${ }^{2}$ Ika Buana Januarti, ${ }^{3}$ Siti Maesaroh \\ ${ }^{1}$ Prodi Profesi Dokter, Fakultas Kedokteran, Universitas Islam Sultan Agung, Semarang, Indonesia \\ ${ }^{2}$ Prodi Farmasi, Fakultas Kedokteran, Universitas Islam Sultan Agung, Semarang, Indonesia \\ ${ }^{3}$ Universitas Setia Wali Sembilan, Semarang, Indonesia \\ *Corresponding Author \\ Jl. Raya Kaligawe KM 4 Semarang, Jawa tengah, Indonesia \\ Telp. 024-6583584, Fax. 024-6594366 \\ E-mail: ahmadinh21@gmail.com
}

Received:

31 August 2019
Revised:

19 November 2019
Accepted:

28 November 2019
Published:

30 November 2019

\begin{abstract}
Abstrak
Mahasiswa program terminasi Fakultas Kedokteran UNISSULA adalah mahasiswa yang masa studinya tinggal satu semester, untuk membantu mahasiswa agar dapat menyelesaikan studinya dengan baik, maka penting dilakukan Program Kemitraan Masyarakat (PKM) intervensi psikososial sehingga mahasiswa yang terkena ketentuan terminasi dapat meneriman kenyataan yang ada dan merasa optimis. Artikel dibuat untuk mengetahui data demografi mahasiswa dan kondisi psikososial mahasiswa dalam menerima ketentuan terminasi. Metode yang digunakan adalah dengan mengumpulkan mahasiswa terminasi hasil yudisium periode genap tahun akademik 2017 selanjutnya diberikan PKM intervensipsikosial, ceramah motivasi belajar, tujuan hidup manusia, role model oleh mahasiswa lain yang telah berhasil studinya, rencana kedepan dan komitmen bersama, selanjutnya diberikan post tes untuk mgetahui hasil intervensi psikososial yang telah diberikan. Hasil dari studi ini adalah bahwa terdapat lima belas (15) mahasiswa terminasi yang mengikuti PKM intervensi psikososial, jenis kelamin terbanyak adalah laki-laki ada 9 mahasiswa (60\%), alamat terbanyak di Jawa Tengah ada 10 mahasiswa $(66,7 \%)$, tempat tinggal terbanyak rumah sendiri ada 8 mahasiswa $(53,3 \%)$, keinginan masuk Fakultas Kedokteran terbanyak adalah keinginan sendiri ada 7 mahasiswa (46,7 \%), menyukai Fakultas Kedokteran ada 14 mahasiswa (93,3 $\%$ ), tahun masuk ke Fakultas Kedokteran terbanyak tahun 2009 ada 11 mahasiswa (73,3 \%). Setelah dilakukan PKM intervensi psikososial didapatkan mahasiswa sangat membutuhkan akan adanya intervensi, intervensi psikososial sangat membantu memahami permasalahan mahasiswa, intervensi psikososial sangat membantu membawa perubahan pikiran dan perasan lebih baik, intervensi psikososial sangat bermanfaat dan sangat membantu menyelesaikan permasalahan mahasiswa. Mengetahui kondisi mahasiswa dalam menerima ketentuan terminasi, memberikan solusi, dukungan emosional dan pemahaman bahwa di balik permasalahan pasti ada hikmahnya.
\end{abstract}

Kata kunci: intervensi psikososial; mahasiswa terminasi; FK UNISSULA. 


\begin{abstract}
UNISSULA Faculty of Medicine termination program students are students who have only one semester of study period, to help students to be able to complete their studies well, it is important to do a Community Service Program (PKM) for psychosocial interventions so that students affected by termination provisions can accept the existing reality and feel optimistic. The article was made to find out student demographic data and student psychosocial conditions in accepting termination provisions. The method used is to collect students termination results of the 2017 academic year even period later given PKM social psychological intervention, learning motivation lectures, human life goals, role models by other students who have successfully studied, future plans and joint commitment, then given a post-test to find out the results of psychosocial interventions that have been given. The results of this study are that there were fifteen (15) termination students who took the PKM psychosocial intervention, the most gender was 9 male students (60\%), the highest address in Central Java there were 10 students (66.7\%), most of their own homes have 8 students (53.3\%), the most desires to enter the Faculty of Medicine are 7 students (46.7\%) of their own desires, like the Faculty of Medicine there are 14 students (93.3\%), the year of entering the Faculty In 2009 there were 11 students (73.3\%). After PKM psychosocial intervention was found, students really needed an intervention, psychosocial intervention really helped to understand students' problems, psychosocial intervention really helped bring a change of mind and feel better, psychosocial intervention was very useful and really helped solve student problems. Knowing the condition of students in accepting termination provisions, providing solutions, emotional support and understanding that behind the problem there must be a silver lining.
\end{abstract}

Keywords: psycho-social intervention; termination program; FK UNISSULA.

\title{
PENDAHULUAN
}

Program Pendidikan Sarjana Kedokteran (PPSK) di Fakultas Kedokteran Universitas Islam Sultan Agung (UNISSULA) Semarang ditempuh dalam waktu tiga setengah $(3,5)$ semester atau tiga setengah $(3,5)$ tahun dengan toleransi waktu dua (2) kali masa studi yaitu tujuh (7) tahun, setelah masa studi tersebut habis bila mahasiswa tidak dapat menyelesaikan studinya, maka mahasiswa dinyatakan habis masa studinya dan akan terkena ketentuan drop out (DO). Mahasiswa program terminasi Fakultas Kedokteran UNISSULA adalah mahasiswa yang masa studinya tinggal satu (1) semester, untuk bisa membantu mahasiswa terminasi agar dapat menyelesaikan studinya dengan baik dan tidak terkena ketentuan drop out, maka penting dilakukan PKM intervensi psikososial. PKM intervensi psikososial selain untuk tujuan membantu mahasiswa agar berhasil dalam studinya., juga untuk membantu mahasiswa agar tertap semangat dalam menyelesaikan studi, mahasiswa tetap optimis dalam menghadapi ketentuan terminasi, mahasiswa dapat menemukan jalan keluar dengan baik, walaupun terlambat akhirnya mahasiswa dapat menyelesaikan studinya, tetapi bila dikemudian hari nantinya ternyata ada mahasiswa yang terkena ketentuan drop out dengan PKM pemberian PKM intervensi psikososial tersebut, diharapkan mahasiswa dapat menerima kenyataan yang ada, mahasiswa akian bisa bertawakal kepada Allah SWT, mahasiswa tetap merasa optimis, berfikiran positif, meyakini bahwa dibalik permasalahan yang menimpa manusia apasti ada jalan keluarnya dan dikemudian hari pasti ada hikmahnya yang baik.

Permasalahan yang dihadapi oleh mahasiswa Fakultas Kedokteran cukup banyak dan kompleks, meliputi berbagai permasalahan akademik dan permasalahan non akademik. 
Permasalahan akademik seperti ketidak harhadiran dalam studi, pemahaman materi kuliah, prestasi nilai akademik kurang, kurang tersedianya buku-buku pustaka, dan lain-lain. Sedangkan permasalahan non akademik meliputi permasalahan keluarga/orang tua, permasalahan dengan teman bergaul, permasalahan keuangan, permasalahan tempat tinggal tidak nyaman tidak kondusif, permasalahan tidak bisa membagi waktu dalam menyalurkan minat dan bakat, permasalahan etika, permasalahan krimainal, dan lai-lain. Demikian juga permasalahan yang dialami oleh mahasiswa Fakultas Kedokteran UNISSULA Semarang dalam menempuh studinya sebagian mahasiswa ada yang mengalami hambatan dan kesulitan, mengalami permasalahan baik itu masalah akademik maupun non akademik. Menurut ketentuan yang terdapat dalam buku bimbingan konseling mahasiswa Fakultas Kedokteran UNISSULA Semarang edisi IX tahun 2017 menyatakan bahwa mahsiswa yang mengalami permasalahan dalam studinya perlu direferal untuk mendapatkan bantuan dukungan perkembangan dan bantuan menyelesaikan permasalahan yang sedang dihadapi. Adapun ketentuan mahasiswa yang akan mendapatkan PKM intervensi psikososial adalah: 1) mahasiswa yang mengulang mata pelajaran atau modul tertentu sudah tiga (3) kali atau lebih masih belum lulus atau telah mencapai semester ke tiga (3) dengan perolehan IPK kurangt dari 2,5. 2) Mahasiswa yang tidak aktif kegiatan akademik selama satu (1) semester atau lebih. 3) Mahaiswa yang sering bolos atau tidak aktif dalam mengikuti kegiatan akademik, seperti diskusi kelompok kecil (SGD), skill lab, kuliah pakar dan kegiatan akademik lainnya. 4) Mahasiswa dengan permasalahan bioetika atau kriminal, seperti pemalsuan tanda tangan sesama mahasiswa, pemalsuan tanda tangan dosen, pemalsuan nilai akademik, pencurian uang/barang dan lain-lain.

PKM intervensi psikososial berupa bimbingan konseling merupakan proses interaksi secara sistematis, objektif, logis, dan berkelanjutan serta terprogram yang dilakukan oleh seorang konselor atau dosen pembimbing akademik kepada konseli atau mahasiswa bimbingannya untuk memfasilitasi perkembangan potensi yang dimilikik mahasiswa secara optimal dengan jalan memahami diri sendiri dan lingkungannya ataupun mengatasi hambatan dan permasalahan yang sedang dialami oleh mahasiswa/konseli dalam studinya untuk mencari jalan keluar, mencapai kesuksesan studi dan kemandirian mahasiswa dalam kehidupannya. ${ }^{(1)}$

PKM intervensi psikososial berupa bimbingan konseling memiliki berbagai fungsi, seperti: fungsi pemahaman, fungsi preventif atau pencegahan, fungsi dukungan pengembangan, dan fungsi pemecahan masalah/solusi atau penyembuh. 1) Fungsi pemahaman diberikan kepada mahasiswa agar mampu memahami potensi yang dimiliki oleh dirinya sendiri dan lingkungannya serta mampu menggali potensi tersebut secara optimal sehingga mahasiswa dapat menyesuaikan dirinya dengan lingkungan yang sedang dihadapi secara baik, dinamis dan konstruktif. 2) Fungsi preventif atau pencegahan adalah senantiasa mengantisipasi dan waspada terhadap berbagai permasalahan yang mungkin dihadapi mahasiswa dan berupaya agar mahasiswa bisa mencegah dan mengatasinya dengan baik. 3) Fungsi dukungan pertumbuhan dan pengembangan, fungsi ini memberikan dukungan pengembangan kearah pengembangan yang sehat dan lebih baik, dengan menciptakan lingkungan belajar yang kondusif, memfasilitasi adanya layanan informasi, kegiatan tutorial klinik, diskusi kasus, atau curah pendapat (brain storming), kunjungan rumah, dan karyawisata. 4) Fungsi pemecahan masalah atau penyembuh, fungi ini bersifat kuratif dengan upaya pemberian bantuan atau solusi pemecahan masalah yang disepakati bersama antara konselor atau dosen wali dengan mahasiswa yang sedang mengalami permasalahan, baik yang menyangkut masalah akademik, masalah pribadi, masalah keluarga maupun permasalahan-permasalahan psikososial lainnya.

Selain fungsi tersebut layanan bimbingan dan intervensi psikososial juga memiliki fungsi sebagai berikut: a) membantu penyesuaian diri mahasiswa dengan diri sendiri dan lingkungan; b) penyaluran dalam pilihan modul, pendidikan, pekerjaan, dan karir; c) Pemeliharaan kondisi pribadi dan situasi yang kondusif untuk perkembangan diri; d) advokasi diri terhadap perlakuan diskriminatif mahasiswa; dan e) Membangun adaptasi pendidik dan 
tenaga kependidikan terhadap program dan aktivitas pendidikan sesuai dengan latar belakang pendidikan, bakat, minat, kemampuan, kecepatan belajar.

PKM intervensi psikososial dengan bimbingan konseling memiliki tujuan membantu mencapai perkembangan optimal dan kemandirian dalam aspek pribadi, belajar, sosial, dan karir. Dimana pelaksanaan bimbingan dan intervensi psikososial dilaksanakan dengan asas: a) kerahasiaan sebagaimana diatur dalam kode etik bimbingan dan intervensi psikososial; b). Kesukarelaan dalam mengikuti layanan yang diperlukan; c). Keterbukaan dalam memberikan dan menerima informasi; d). Keaktifan dalam penyelesaian masalah; e). kemandirian dalam pengambilan keputusan; f). Kekinian dalam penyelesaian masalah yang berpengaruh pada kehidupan; g). Kedinamisan dalam layanan dan menggunakan teknik layanan sejalan dengan perkembangan ilmu bimbingan dan intervensi psikososial terkini; h). keterpaduan kerja antar pemangku kepentingan pendidikan; i). Keharmonisan layanan dengan visi dan misi satuan pendidikan, serta nilai dan norma kehidupan yang berlaku di masyarakat; j). Keahlian dalam pelayanan yang didasarkan pada kaidah-kaidah akademik dan profesional di bidang bimbingan dan intervensi psikososial; k). Tut wuri handayani dalam memfasilitasi setiap peserta didik untuk mencapai tingkat perkembangan yang optimal.

PKM intervensi psikososial dengan bimbingan konseling dilaksanakan berdasarkan prinsip: a). Diperuntukkan bagi semua dan tidak diskriminatif; b) Merupakan proses individuasi; c) Menekankan pada nilai yang positif; d) Merupakan tanggung jawab bersama antara pimpinan, konselor atau guru bimbingan dan intervensi psikososial, dan pendidik lainnya dalam satuan pendidikan; e) Mendorong konseli untuk mengambil dan merealisasikan keputusan secara bertanggung jawab; f) Berlangsung dalam berbagai latar kehidupan; g) Merupakan bagian integral yang tidak terpisahkan dari proses pendidikan; h) Dilaksanakan dalam bingkai budaya Indonesia; i). Bersifat fleksibel dan adaptif serta berkelanjutan; j) Dilaksanakan sesuai standar dan prosedur profesional bimbingan dan intervensi psikososial; dan $\mathrm{k}$ Disusun berdasarkan kebutuhan konseli. Adapun komponen layanan bimbingan dan intervensi psikososial memiliki empat (4) program yang mencakup: a) Layanan dasar; b). Layanan peminatan dan perencanaan individual; c) Layanan responsif; dan d) Layanan dukungan sistem. Untuk bidang layanan bimbingan dan intervensi psikososial mencakup: a) Bidang layanan pribadi; b) Bidang layanan belajar; c) Bidang layanan sosial; dan d) Bidang layanan karir.

Dalam intervensi psikososial dengan bimbingan konseling ini akan diberikan melalui beberapa fase sebagai berikut, fase 1: Membentuk pola pertemuan yang bersifat terapeutik, agar terjadi situasi yang memungkinkan terjadinya perubahan pola pikir dan perilaku klien kearah yang positif, fase 2: Meyakinkan $\mathrm{klien} / \mathrm{mahasiswa}$ agar bersedia dan merasa nyaman dan aman untuk mengikuti prosedur intervensi psikososial dengan baik, fase 3: Mendorong klien untuk bersedia mengungkapkan pikiran, perasaan dan keinginan-keinginan sebenarnya yang terpendam dengan terbuka, tidak merasa berat untukmmengungkapkan apa adanya sesuai yang terjadi dan sesuai yang dialaminya, fase 4: Setelah klien bisa memahami dan mampu mengungkapkan pikiran, perasaan, dan keinginannya secara terbuka sesuai dengan kenyataan yang ada, selanjutnya klien harus sudah bisa dan mampu menemukan jati dirinya secara integral, utuh, kuat untuk melangkah kedepan menuju kesuksesan dengan mantap, tidak mesasa gagal, tidak merasa inferior, dan tidak merasa tidak berguna, dll, walaupun keinginan awalnya yang diinginkan tidak terpenuhi, mengalami kendala fdan kegagalan, klien bisa memahami dan menerima kondisi yang ada atau permasalahan yang sedang dihadapi pada dirinya saat ini, kedepan klien harus merasa lebih semanagat dan percaya diri untuk maju menuju sukses dalam studinya, dan terakhir fase 5: Mengakhiri pertemuan dengan rara lebih nyaman, tidak ada beban, klien tidak merasa gagal dan bersalah, dan tidak saling menyalahkan, klien bisa memahami dan menerima dirinya sendiri dengan sebenarnya, klien tumbuh rasa semangat, rasa ingin bangkit, penuh percaya diri menuju sukses dengan mantap. 


\section{METODE}

Metode yang digunakan adalah dengan pendekatan rancangan penelitian kuantitatif dan kualitatif sederhana, obyek sasaran dalam program kemitraan masyarakat intervensi psikososial ini adalah mahasiswa Fakultas Kedokteran program pendidikan sarjana Kedokteran fase terminasi hasil yudisium periode grenap tahun akademik 2016/2017. Obyek penelitian yang akan diberikan intervensi psikososial dipilih dengan cara mengumumkan terlebih dahulu di papan pengumuman Fakultas Kedokteran gedung A atau gedung Al-Kindi dengan mencantumkan daftar nama-nama mahasiswa fase terminasi, jadwal acara kegiatan intervensi psikososial, tempat dan hari tanggal pelaksanaannya, intervensi psikososial akan dilaksanakan dua hari, yaitu pada hari jumat dan hari sabtu tanggal 29 dan 30 September tahun 2017, bertempat di gedung C lantai satu Fakultas Kedokteran atau gedung Ibnu Rusyd. Mahasiswamahsiswa tersebut diminta untuk bisa hadir mengikuti kegiatan intervensi psikososial, selain dengan pengumuman mahasiswa juga dipanggil lewat surat, dengan WA dan juga ditelpon oleh staf administrasi Unit Bimbingan Konseling (UBK). Setelah mahasiswa hadir dan berkumpul dalam ruangan yang telah disediakan, mahasiswa dimita mengisi daftar absensi kehadiran, selanjutnya dilakukan intervensi psikososial dan bimbingan konseling, sesuai dengan jadwal dan materi yang telah disampaikan. Pelaksanaan program kemitraan masyarakat intervensi psikososial dan bimbingan konseling bagi mahasiswa terminasi dapat dilihat dalam gambar (1).

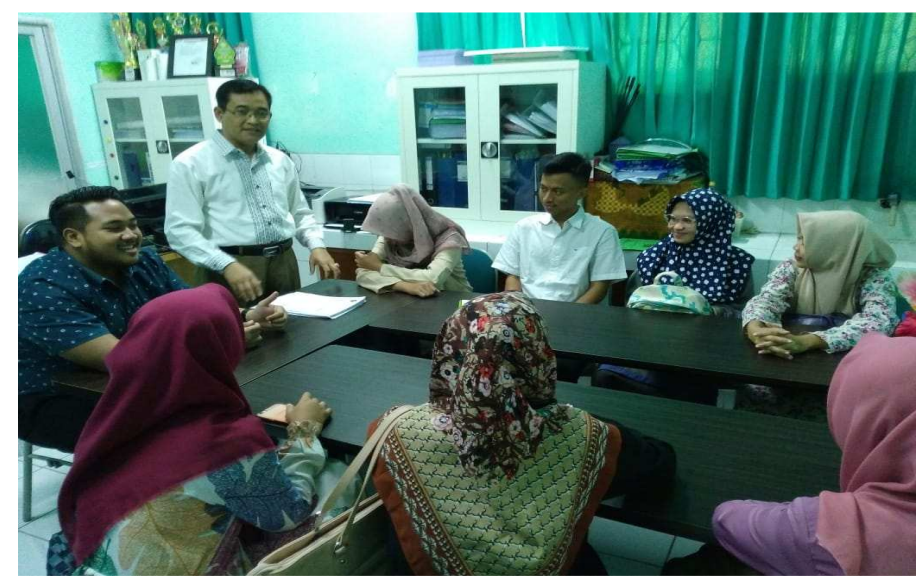

Gambar 1. Intervensi psikososial kelompok mahasisawa terminasi

Program kemitraan masyarakat intervensi psikososial dilakukan dengan langkah-langkah sebagai berikut:

1) Mahasiswa yang bersedia hadir diminta mengisi absensi daftar hadir dan tanda tangan sebagai bukti telah mengikuti kegiatan program kemitraan masyarakat intervensi psikososial dan bimbingan konseling.

2) Diberikan kuesioner pre test dengan mengisi data identitas mahasiswa dan data-data terkait akademik mahasiswa. Data identitas mahasiswa meliputi: nama mahasiswa, nomer induk mahasiswa, jenis kelamin mahasiswa, alamat asal, tempat tinggal, masa studi mahasiswa, dan nilai indek prestasi akademik (IPK) komulatif mahasisa. Selanjutnya, data-data terkait akademik mahasiswa meliputi sebagai berikut: data sebelum masuk Fakultas Kedokteran UNISSULA apakah mahasiswa menyukai Fakultas Kedokteran, atas keinginan siapa pada waktu mahasiswa masuk Fakultas Kedokteran UNISSULA, melalui jalur apa pada waktu mahasiswa masuk Fakultas Kedokteran UNISSULA, berapa lama rencana masa`studi yang akan diinginkan mahasiswa pada waktu menempuh sarjana kedokteran, ada berapa modul yang belum lulus, ada berapa modul yang sedang diulang sebelum ujian khusus, berapakah indeks prestasi akademik komulatif (IPK) sebelum ujian khusus, berapa modul yang belum 
lulus sesudah mengikuti ujian khusus, berapakah IPK komulatif setelah mengikuti ujian khusus, dan apa harapan ke depan mahasiswa setelah lulus program sarjana kedokteran. Selanjutnya mahaiswa diminta mengisi kuesioner terbuka dengan dibimbing oleh konselor mengenai permasalahan akademik dan permasalahan non akademik mahasiswa serta solusi pemecahan terhadap permasalahan tersebut yang akan ditempuhnya minimal tiga permasalahan dan tiga solusi pemecahan permasalahan.

3) Ceramah motivasi belajar mahasiswa diminta agar tetap semangat dan optimis diminta belajar yang sungguh-sungguh disertai berdoa, tujuan hidup manusian dijelaskan bahwa tujuan hidup manusia adalah pada hakekatnya untuk ibadah kepada Allah SWT, nasib manusia dijelaskan bahwa setelah manusi berusaha dengan segenap kemampuaanya hasil akhir dikemudian hari pada hakekatnya yang menentukan adalah allah SWT, usaha dan takdir, setelah manusia berusaha dengan sungguh-sungguh dan dengan segenap kemampuannya, ternyata hasilnya ada yang sesuai dengan harapan dan ada juga yang tidak sesuai harapan, hal tersebut tidak terlepas dengan takdir Allah SWT dan harus bisa disadari dan diterima dengan lapang ada.

4) Role model bio psikososial dilakukan dengan menampilkan sesama mahasiswa prodi sarjana kedokteran yang telah berhasil dalam studinya denganh IPK lebih di atas 3 sebagai syarat kelulusan, disampaikan oleh 2 mahasiswa dengan menceritakan pengalaman-pengalaman masing-masing personal terkait keberhasilannya dalam studi dan bagaimana mensikapi kendala-kendala yang pernah dihadapinya serta solusi pemecahannya, bio psikososial role model ini disampaikan untuk lebih memotivasi mahasiswa agar tetap semangat belajar dalam menyelesaikan studinya, ingat kepada orang tua yang telah bersusah payah membiayainya walaupun terlambat ada kendala dan permasalahan yang pernah dihadapi harus tetap optimis tidak boleh menyerah dan tetap semangat untuk bisa menyelesaikan studinya denganb baik.

5) Program Kemitraan Masyarakat (PKM) intervensi psikososial dan bimbingan konseling kelompok kecil. PKM intervensi psikososial dan bimbingan konseling kelaompok kecil ini akan dibagi dua (2) kelompok yaitu: kelompok satu (1) akan diampu dengan instrukter Dr. dr. H. Ahmadi NH., SpKJ sebagai ketua PKM intervensi psikososial dan bimbingan konseling yang kelompok ke dua (2) diampu oleh ibu Dra. Ikha Buana, M.Sc sebagai sekretaris PKM intervensi psikososial dan bimbingan konseling. Dalam PKM intervensi psikososial dan bimbingan konseling kelompok kecil ini mahasiswa diberikan penjelasan dan bimbingan oleh konselor masing-masing diberikan penjelasan bagaimana mahasiswa bisa mengerti dan memahami permasalahan-permasalahannya yang sedang dihadapi, permasalahan-permasalahan yang menghambat dalam studinya, selanjutnya mahasiswa diminta menggali sendiri dengan dimotivasi dan dipandu oleh konselor, untuk mengeksplorasi permasalahan akademik dan permasalahan non akademik yang pernah dihadapi, dan juga rencana solusi pemecahan yang sekiranya secara riil bisa dikerjakan dengan dibimbing oleh konselor sebagai instruktur, bila sudah menemukan permasalahan dan rencana solusi pemecahan secara konkrit dan sekiranya bisa dikerjakan dengan baik, selanjutnya mahasiswa diminta menandatangi surat pernyataan kesepakatan komitmen diatas kertas bermeterai, dengan diketahui oleh konselar atau instruktur.

6) Mahasiswa diminta membacakan surat pernyatan kesepakatan terkait permasalahan solusinya tersebut dihadapan konselor atau instruktur untuk berkomitmen dengan sungguhsungguh dalam menyelesaikan studinya dan rencana evaluasi ke depan.

7) Mahasiswa dikumpukan kembali ke dalam kelas besar untuk dilakukan pos tes terkait program kemitraan masyarakat intervensi psikososial dan bimbingan konseling.

Dalam intervensi psikososial kelompok besar kedua (2) mahasiswa akan diberikan materi dengan mengisi kuesioner yang telah disediakan meliputi hal-hal sebagai berikut: (1) keberadaan program kemitraan masyarakat intervensi psikososial dan bimbingan konseling 
dibutuhkan atau tidak, (2) PKM intervensi psikososial dan bimbingan konseling dapat membantu mahasiswa dalam memahami permasalahan yang dihadapi atau tidak, (3) PKM intervensi psikososial dan bimbingan konseling dapat membantu mahasiswa dalam perubahan pikiran dan perasaan kearah yang lebih baik atau tidak, (4) PKM intervensi psikososial dan bimbingan konseling bermanfaat atau tidak, dan (5) PKM intervensi psikososial dan bimbingan konseling dapat membantu mahasiswa dalam menyelesaikan permasalahan yang sedang dihadapi atau tidak. Langkah selanjutnya yaitu langkah ke 8) penutup. Kemudian data-data tersebut dikelompokkan sesuai dengan konten dan permasalahan solusinya, selanjutnya dilakukan analisis diskriptif dan analisis kuantitatif sederhana untuk kemudian dibuat laporannya.

\section{HASIL DAN PEMBAHASAN}

Subyek penelitian dalam pengabdian pengabdian masyarakat adalah mahasiswa fase terminasi program pendidikan sarjana kedokteran Fakultas Kedokteran UNISSULA Semarang periode genap tahun akademik 2016/2017, subyek diambil berdasarkan Surat Keputusan (SK) Dekan Fakultas Kedokteran UNISSULA Semarang dengan nomor: 2214/A.2/SA-K/X/2017. Dari hasil yudisum dan keputusan surat Dekan tersebut didapatkan mahasiswa Fakultas Kedokteran program pendidikan sarjana kedokteran fase terminasi yang besedia mengikuti PKM intervensi psikososial dan bimbingan konseling dan besedia mengisi kuesioner kemudian mengembalikan kuesioner tersebut sebanyak 15 mahasiswa, selanjutnya akan dianalisis data demografi mahasiswa disajikan dalam tabel 1.

Tabel 1. Data demografi mahasiswa

\begin{tabular}{|c|c|c|c|c|}
\hline \multirow{2}{*}{ Jenis Kelamin } & Laki-Laki & $\%$ & Perempuan & $\%$ \\
\hline & 9 & $60 \%$ & 6 & $40 \%$ \\
\hline \multirow{2}{*}{ Tahun Masuk } & 2009 & $\%$ & 2008 & $\%$ \\
\hline & 11 & $73,3 \%$ & 4 & $26,7 \%$ \\
\hline \multirow{2}{*}{ Alamat } & Jateng & $\%$ & Luar Jateng & $\%$ \\
\hline & 10 & $66,7 \%$ & 5 & $33,3 \%$ \\
\hline \multirow{2}{*}{ Tempat Tinggal } & Rumah Sendiri & $\%$ & Kost / Kontrak & $\%$ \\
\hline & 8 & $53,3 \%$ & 7 & $46,7 \%$ \\
\hline \multirow{2}{*}{ Menyukai FK } & Suka & $\%$ & Tidak & $\%$ \\
\hline & 14 & $93,3 \%$ & 1 & $6,7 \%$ \\
\hline \multirow{2}{*}{ Keinginan Masuk } & Sendiri: & Orang Tua & Gabungan & $\%$ \\
\hline & $7 \quad 46,7 \%$ & 3 & $20 \%$ & $33,3 \%$ \\
\hline
\end{tabular}

Didapat data demografi mahasiswa, berdasarkan data demografi jenis kelamin, didapat jenis laki-laki ada sebanyak 9 mahasiswa (60\%) jenis kelamin perempuan ada sebanyak 6 mahasiswa (40\%), berdasarkan alamat mahasiswa didapat mahasiswa yang beralamat di wilayah jawa tengah ada 10 mahasiswa $(66,7 \%)$ yang beralamat diwilayah luar jawa tengah ada 5 mahasiswa (33,3\%), berdasarkan tempat tinggal, didapat masiswa yang bertempat tinggal di rumah sendiri ada 8 mahasiswa $(53,3 \%)$ yang bertempat tinggal di kos/kontrak ada 7 mahasiswa (46,7.\%), berdasarkan keinginan masuk Fakultas Kedokteran, didapat mahasiswa yang berkeinginan masuk Fakultas Kedokteran atas` keinginan sendiri ada 7 mahasiswa (46,7 $\%$ ) yang bekeinginan masuk Fakultas Kedokteran karena keinginan orang tua ada 3 mahasiswa $(20 \%)$ yang karena keinginan sendiri dan juga orang tua ada 5 mahasiswa (33,3 \%), berdasarkan kesukaan akan Fakultas Kedokteran, didapat mahasiswa yang menyatakan sukan terhadap Fakultas Kedokteran ada 14 mahasiswa (93,3 \%) mahasiswa yang menyatakan tidak suka terhadap Fakultas Kedokteran ada 1 mahasiswa (6,7 \%), berdasarkan tahun masuk ke Fakultas Kedokteran, didapat mahasiswa yang masuk Fakultas Kedokteran tahun 2008 ada 4 mahasiswa $(26,7 \%)$ dan mahasiswa yang masuk Fakultas Kedokteran tahun 2009 ada 11 mahasiswa $(73,3 \%)$. 
Selanjuntanya dilakukan PKM intervensi psikososial dan bimbingan konseling dengan langkah-langkah seperti yang telah disampaikan dalam metode penelitian yang meliputi intervensi psikososial dan konseling kelompok besar, pembukaan, ceramah motivasi, tujuan hidup manusia, nasib manusia, ikhtiar dan taqdir, selanjutnya dilakukian bio psikososial dengan role model dilakukan oleh sesama teman mahasiswa yang telah berhasil lulsdengan IPK di atas tiga, kemudian dbagi menjadi intervensi psikososial kelompokk kecil, diberikan penjelasan dan pemaham mengenai permasalahan mahasiswa dan bagaimana mencari solusinya, selanjutnya mahasiswa membuat penyataan komitmen dan membacakan bersama dengan disaksiklan oleh konselor, kemudian mahasiswa diminta menandatangani surat pernyataan komitmen tersebut dihadapan konselor, demikian juga konselor juga melakukan tangan bersama dalam surat penyataan komitmen mhasiswa tersebut, setelah itu kembali ke ruangan intervensi psikososial kelompok besar lagi, untuk dilakuan pembagian dan pengisian kuesioner post tes dan penutupan. Respon mahasiswa terhadap pelaksanaan PKM intervensi psikososial dan bimbingan konseling dapat dilihat dalam tabel 2.

Tabel 2. Data respon mahasiswa terhadap PKM intervensi psikososial

\begin{tabular}{|c|c|c|c|c|c|c|c|c|}
\hline \multirow{2}{*}{ No } & \multirow{2}{*}{ PERTANYAAN } & \multicolumn{6}{|c|}{ RESPON } & \multirow{2}{*}{ JUMLAH } \\
\hline & & YA & $\%$ & CUKUP & $\%$ & TIDAK & $\%$ & \\
\hline 1 & $\begin{array}{l}\text { Apakah } \\
\text { keberadaan PKM } \\
\text { intervensi } \\
\text { psikososial dan } \\
\text { BK sangat } \\
\text { dibutuhkan? }\end{array}$ & 13 & $86,70 \%$ & 2 & $13,30 \%$ & 0 & $0 \%$ & 15 \\
\hline 2 & $\begin{array}{l}\text { Apakah PKM } \\
\text { intervensi } \\
\text { psikososial dan } \\
\text { BK membantu } \\
\text { memahami } \\
\text { permasalahan } \\
\text { mahasiswa? }\end{array}$ & 11 & $73,30 \%$ & 4 & $26,70 \%$ & 0 & $0 \%$ & 15 \\
\hline 3 & $\begin{array}{l}\text { Apakah PKM } \\
\text { intervensi } \\
\text { psikososial dan } \\
\text { BK membawa } \\
\text { perubahan pikiran } \\
\text { \& perasaan lebih } \\
\text { baik? }\end{array}$ & 10 & $66,70 \%$ & 5 & $33,30 \%$ & 0 & $0 \%$ & 15 \\
\hline 4 & $\begin{array}{l}\text { Apakah PKM } \\
\text { intervensi } \\
\text { psikososial dan } \\
\text { BK bermanfaat } \\
\text { untuk anda? }\end{array}$ & 11 & $73,30 \%$ & 4 & $26,70 \%$ & 0 & $0 \%$ & 15 \\
\hline 5 & $\begin{array}{l}\text { Apakah PKM } \\
\text { intervensi } \\
\text { psikososial dan } \\
\text { BK membantu } \\
\text { menyelesaikan } \\
\text { masalah anda? }\end{array}$ & 11 & $73,30 \%$ & 4 & $26,70 \%$ & 0 & $0 \%$ & 15 \\
\hline
\end{tabular}


Setelah dilakukan PKM intervensi psikososial dan bimbingan konseling tersebut dari hasil isian mahasiswa dalam kuesioner post tes didapatkan respon mahasiswa yang cukup beragam, berikut akan disampaikan beberapa respon mahasiswa setelah mengikuti kegiatan PKM intervensi psikososial dan bimbingan konseling, dimana didapatkan respon sebagai berikut: a) mahasiswa yang menyatakan akan kebutuhan terhadap keberadaan PKM intervensi psikososial dan bimbingan konseling, mahasiswa yang menyatakan sangat dibutuhkan ada 13 mahasiswa (86,7 \%), cukup dibutuhkan ada 2 mahasiswa (13,3\%), dan yang menyatakan tidak dibutuhkan 0 mahasiswa (0 \%), b) mahasiswa yang menyatakan bahwa PKM intervensi psikososial dan bimbingan konseling membantu mahasiswa dalam memahami akan permasalahannya, didapatkan mahasiswa yang menyatakan bahwa PKM intervensi psikososial dan bimbingan konseling sangat membantu ada 11 mahasiswa (73,3\%), cukup membantu ada 4 mahasiswa $(26,7 \%)$, tidak membantu 0 mahasiswa $(0 \%)$, c) mahasiswa yang menyatakan bahwa bimbingan intervensi psikososial membantu membawa pikran dan perasaan mahasiswa kearah lebih baik, ya sangat membantu ada 10 mahasiswa $(66,7 \%)$ cukup membantu ada 5 mahasiswa ( 33,3 \%) menyatakan tidak membantu ada 0 mahasiswa $(0 \%)$, d) mahasiswa yang menyatakan bahwa PKM intervensi psikososial dan bimbingan konseling bermanfaat bagi mahasiswa, yang menyatakan sangat bermanfaat ada 11 mahasiswa $(73,3 \%)$ cukup bermanfaat ada 4 mahasiswa (26,7 \%) menyatakan tidak bermanfaat 0 mahasiswa $(0 \%)$, e) mahasiswa yang menyatakan apakah PKM intervensi psikososial dan bimbingan konseling membantu menyelesaikan masalah mahasiswa, yang menyatakan sangat membantu ada 11 mahasiswa $(73,3 \%)$ cukup membantu ada 4 mahasiswa $(26,7 \%)$ tidak membantu ada 0 mahasiswa (0 \%).

\section{KESIMPULAN}

Didapatkan data demografi mahasiswa PKM intervensi psikososial dan bimbingan konseling sebagai berikut: a) Berdasarkan jenis kelamin mahasiswa yang terbanyak adalah laki-laki, b) Alamat mahasiswa yang terbanyak adalah berdomisili di wilayah Jawa Tengah, c) Tempat tinggal mahasiswa yang terbanyak adalah di rumah sendiri, d) Keinginan mahasiswa masuk Fakultas Kedokteran terbanyak adalah atas keinginan sendiri, e) Kesukaan mahasiswa terhadap Fakultas Kedokteran mahasiswa terbanyak adalah menyukai Fakultas Kedokteran, dan f) Berdasarkan tahun masuk mahasiswa terbanyak adalah masuk Fakultas Kedokteran UNISSULA pada tahun 2009.

Adapun respon mahasiswa terhadap pelaksanaan PKM intervensi psikososial dan bimbingan konseling juga bervariasi, respon terbanyak adalah mahasiswa menyatakan bahwa intervensi psikososial: a) sangat membantu dan bermanfaat bagi mahasiswa Fakultas Kedokteran program studi pendidikan sarjana Kedokteran (S1) fase terminal hasil yudisium periode genap tahun akademik 2017, b) bahwa keberadaan PKM intervensi psikososial dan bimbingan konseling sangat dibutuhkan oleh mahasiswa, c) PKM intervensi psikososial dan bimbingan konseling sangat membantu mahasiswa dalam memahami permasalahannya, d) PKM intervensi psikososial dan bimbingan konseling sangat membantu mahasiswa dalam membawa perubahan pikiran dan perasaan kearah yang lebih baik, e) PKM intervensi psikososial dan bimbingan konseling sangat bermanfaat bagi mahasiswa yang sedang mengalami permasalahan dan hambatan dalam studi, f) PKM intervensi psikososial dan bimbingan konseling sangat membantu mahasiswa dalam menyelesaikan permasalahan yang sedang dihadapi.

Bahwa keberadaan PKM intervensi psikososial dan bimbingan konseling harus tetap dipertahankan dan diberikan terutama kepada mahasiswa yang sedang mengalami permasalahan baik itu permasalahan akademik maupun permasalahan non akademik agar mahasiswa mendapatkan jalan keluar yang baik, mahasiswa dapat menyelesaikan studinya di Fakultas Kedokteran, tidak terkena drop out (DO) tetap merasa nyaman, bahagia dan percaya diri dalam kehipunnya sehari-hari. 


\section{DAFTAR PUSTAKA}

Abdisita, S. (2017). Lima kunci sukses hidup. Solo: Penerbit Tinta Median.

Abdullah, W., Abi Badra Maulana, Muhaji Fikriono (2013). Beyond Motivation. Jakarta: Mizan Publika.

Fakultas`Kedokteran UNISSULA (2017). Buku Pedoman akademik Tahun Akademik 2017. UNISSULA Press, Semarang Tahun 2017, hal: 49.

Gerald, C. (2001). Theory and Practice of Counseling and Psychotherapy. USA Tahun 2001, Hal: 50-6

Ibrahim, E. (2014). Terapi Berpikir Positif. Zaman Transforming Lives, Jakarta.

Mendikbud (2014). Peraturan Menteri Pendidikan Dan Kebudayaan Republik Indonesia No. 111 Tentang Bimbingan Dan Konseling Pada Pendidikan Dasar Dan Pendidikan Menengah .Menteri Pendidikan Dan Kebudayaan Republik Indonesia, Jakarta.

Safitri, A. (2018). Pengembangan Media Pembelajaran Visual Dengan Menggunakan Flipchart Untuk Meningkatkan Motivasi Berprestasi Melalui Layanan Bimbingan Kelompok : Universitas Negeri Jakarta.

Sulistyarini \& Mohammad Jauhar (2014). Dasar-Dasar Konseling. Prestasi Pustaka. ISBN 978-602-256-018-0. Halaman 2-3.

Syamsudin, Amir. (2014). Bimbingan Dan Konseling Pada Pendidikan Dasar Dan Pendidikan Menengah : Peraturan Menteri Pendidikan Dan Kebudayaan Republik Indonesia Nomor 111.

Unit Bimbingan dan Konseling FK UNISSULA (2014). Buku Bimbingan Konseling Untuk Pembimbing Akademik dan Tim Konseling Fakultas`Kedokteran UNISSULA Tahun 2014. UNISSULA Press Semarang. Edisi VI Tahun 2014.hal: 5.

Unit Bimbingan dan Konseling FK UNISSULA (2017). Buku Aktifitas Akademik Bimbingan Konseling Mahasiswa Fakultas 'Kedokteran UNISSULA Tahun 2017. UNISSULA Press, Semarang.

Unit Bimbingan dan Konseling FK UNISSULA (2012). Buku Materi Pelatihan Dosen pembimbing Akademik dan Konseling Sederhana. UNISSULA Press, Semarang. 